Received: May 27, 2010

Accepted after revision: November 8, 2010 Published online: May 18, 2011

\title{
Immune Regulation by CD4+CD25+ Regulatory T Cells in Patients with Japanese Cedar Pollinosis
}

\author{
Takahiro Yamanishi Kazuaki Chikamatsu Goro Takahashi Shuichiro Endo \\ Keisuke Masuyama \\ Department of Otolaryngology-Head and Neck Surgery, University of Yamanashi, Faculty of Medicine, Chuo, Japan
}

\section{Key Words}

Allergic rhinitis $\cdot$ Regulatory T cells $\cdot$ Interleukin-10

Japanese cedar pollinosis $\cdot$ Cry $\mathrm{j} 1$

\begin{abstract}
Background: Evidence indicating that $\mathrm{CD} 4+\mathrm{CD} 25+$ regulatory $\mathrm{T}$ (Treg) cells play a crucial role in the maintenance of peripheral $\mathrm{T}$ cell tolerance to allergens has been accumulated. To explore the functional role of Treg cells in patients with Japanese cedar pollinosis, we performed an in vitro investigation of the regulation of immune responses to allergens by Treg cells. Methods: CD4+ and CD4+CD25- T cells obtained from 12 patients with Japanese cedar pollinosis were stimulated with Cry 11 protein and Cry j 1-derived peptide. On day 6, T cells were tested for allergen-specific reactivity using a CFSE-based proliferation assay and cytokine ELISA assays. The frequency of Cryj 1-specific interleukin (IL)10-producing Treg cells was assessed by ELISPOT assays. $\boldsymbol{R e}$ sults: The proportion of proliferated cells induced by allergen stimulation was similar in both CD4+ and CD4+CD25cell cultures. The production of interferon (IFN)- $\gamma$, but not that of IL-5 was significantly enhanced in CD4+CD25- cell cultures compared to that in CD4+ cell cultures. Interestingly, the production of IL-10 was decreased in CD4+CD25- cell cultures. Moreover, Cry j 1-specific IL-10-producing Treg cells were detected in pollen-allergic patients. Conclusion: Our
\end{abstract}

findings suggest that in pollen-allergic patients, Treg cells predominantly suppresses Th1 responses rather than Th2 responses, where allergen-specific IL-10-producing Treg cells may also be responsible for the downregulation of allergenspecific immune responses.

Copyright $\odot 2011$ S. Karger AG, Basel

\section{Introduction}

Allergic diseases are characterized by allergen-specific IgE production and the activation of effector cells, including eosinophils, mast cells and basophils. These events are regulated by a distinct subset of T lymphocytes, Thelper 2 (Th2) cells, which preferentially produce interleukin (IL)-4, IL-5 and IL-13; therefore, allergic diseases have been defined as the inadequate peripheral regulation of allergen-specific T cells in individuals.

The immune system has developed various mechanisms to prevent or minimize such allergen-specific reactivity. Since a subset of regulatory T (Treg) cells has been recognized as an immunosuppressive $\mathrm{T}$ cell subset capable of the induction and maintenance of immunological tolerance to self and nonself antigens [1-3], two major Treg populations, naturally occurring CD4+ CD25+ Treg cells and antigen-induced interleukin (IL)10 -secreting Treg cells, have been described so far $[4,5]$.

\section{KARGER}

Fax +41613061234 E-Mail karger@karger.ch www.karger.com
(ㄷ) 2011 S. Karger AG, Basel

$1018-2438 / 11 / 1562-0187 \$ 38.00 / 0$

Accessible online at:

www.karger.com/iaa
Correspondence to: Dr. Kazuaki Chikamatsu

Department of Otolaryngology-Head and Neck Surgery

University of Yamanashi

1110, Shimokato, Chuo 409-3898 (Japan)

Tel. +81 55273 6769, Fax +81 55273 9670, E-Mail chikamatsu@yamanashi.ac.jp 
Table 1. Clinical characteristics of allergic patients tested in this study

\begin{tabular}{llllll}
\hline & $\begin{array}{l}\text { Age } \\
\text { years }\end{array}$ & Sex & $\begin{array}{l}\text { Japanese cedar } \\
\text { pollen-specific } \\
\text { IgE, UA/ml }\end{array}$ & $\begin{array}{l}\text { RAST } \\
\text { score }\end{array}$ & $\begin{array}{l}\text { HLA- } \\
\text { DPB1*0501 }\end{array}$ \\
\hline AR-1 & 33 & F & 6.79 & 3 & + \\
AR-2 & 38 & M & 2.68 & 2 & + \\
AR-3 & 38 & M & 0.78 & 2 & + \\
AR-4 & 34 & M & 16.50 & 3 & + \\
AR-5 & 25 & F & 6.15 & 3 & + \\
AR-6 & 32 & M & 3.67 & 3 & + \\
AR-7 & 27 & M & 7.83 & 3 & - \\
AR-8 & 26 & F & 23.70 & 4 & - \\
AR-9 & 26 & M & 2.58 & 2 & - \\
AR-10 & 34 & F & 25.30 & 4 & + \\
AR-11 & 36 & M & 3.85 & 3 & + \\
AR-12 & 33 & F & 10.70 & 3 & + \\
\hline
\end{tabular}

Naturally occurring CD4+CD25+ Treg cells are able to inhibit proliferation and cytokine production by effector $T$ cells in an antigen-nonspecific, cytokine-independent, but cell-cell contact-dependent, manner. Moreover, CD4+CD25+ Treg cells specifically express a transcription factor, Foxp3, which is required for their maintenance of suppressive activity. On the other hand, antigeninduced Treg cells are induced in the presence of IL-10, produce high levels of IL-10 and suppress the proliferation and cytokine production of effector T cells in an IL10-dependent manner [6].

To date, the role of CD4+CD25+ Treg cells in allergic diseases has been extensively investigated. Ling et al. [7] reported that allergen-specific Th2 cells from allergic patients were significantly enhanced by the depletion of CD4+CD25+ T cells. Bellinghausen et al. [8] also demonstrated that $\mathrm{CD} 4+\mathrm{CD} 25+\mathrm{T}$ cells from both nonatopic donors and atopic patients inhibited the proliferation and Th2 cytokine production of CD4+CD25- T cells. Thus, CD4+CD25+ Treg cells play a crucial role in the prevention of inappropriate Th2 responses in allergic diseases; however, several reports suggest that the suppressive activity of CD4+CD25+ Treg cells appears to be affected by various factors, including the type of allergen, allergen exposure and individual allergic status [9-11]. In addition, recent studies have demonstrated the presence of allergen-specific CD4+CD25+ Treg cells and/or IL-10-producing CD4+ CD25+ Treg cells in patients with allergic diseases and/or healthy donors. Maggi et al. [12] have identified circulating Der p 1-specific CD4+CD25+FOXP3+ Treg cells from nonatopic and atopic individuals. Nagato et al. [13] have also demonstrated that Bet $\mathrm{v}$ 1-specific CD4+CD25+ FOXP3+ Treg cells are obtained from patients with birch pollen nasal allergy. These findings suggest overlapping allergen-specific subsets within CD4+CD25+ cells and antigen-induced IL-10-secreting Treg cells.

Japanese cedar pollinosis caused by exposure to Cryptomeria japonica pollen is one of the most prevalent allergic diseases in Japan, and two major allergens, Cry $\mathrm{j} 1$ and Cry j 2, have been isolated and specific IgE detected in sufferers. Currently, it is not known how efficiently naturally occurring Treg cells contribute to immune regulation in Japanese cedar pollinosis. Here we show the functional role of CD4+CD25+ Treg cells in patients with Japanese cedar pollinosis. Moreover, our data demonstrate that Cry j 1-specific IL-10-producing CD4+CD25+ Treg cells exist in the peripheral blood of patients with Japanese cedar pollinosis.

\section{Materials and Methods}

\section{Subjects}

Peripheral blood was obtained outside the pollen season from 6 nonallergic healthy donors and 12 allergic patients suffering from Japanese cedar pollinosis, a diagnosis made on the basis of their case history, clinical symptoms and the presence of allergenspecific IgE in the sera (RAST class $>2$ ). The study was approved by the Institutional Review Board at the University of Yamanashi, University Hospital. Written informed consent was obtained from each individual. Characteristics of 12 allergic patients are summarized in table 1 . HLA-DPB1*0501 genotyping was performed using a commercial DP5 typing panel of PCR primers according to the manufacturer's instructions (Dynal, Oslo, Norway).

\section{Cell Culture}

Heparinized venous blood $(40 \mathrm{ml})$ was obtained from all subjects, and peripheral blood mononuclear cells (PBMCs) were isolated by centrifugation over Ficoll-Hypaque gradients (Amersham Biosciences, Uppsala, Sweden), washed and counted after staining with trypan blue dye. CD4+ T cells and CD4+CD25- T cells were isolated using a regulatory $\mathrm{T}$ cell separation kit according to the manufacturer's protocol (Miltenyi Biotec, Gladbach, Germany). Briefly, cells were washed twice and first CD4+ T cells were negatively selected from the PBMCs, followed by positive selection on anti-CD25 magnetic beads, separating CD4+CD25and CD4+CD25+ T cells. CD4- cell fraction was irradiated (30 Gy) and used as antigen-presenting cells (APCs). Responder CD4+ and CD4+CD25- cells $\left(1 \times 10^{5}\right.$ per well $)$ were stained with $1.5 \mu \mathrm{M}$ CFSE (Molecular Probe/Invitrogen, Grand Island, N.Y., USA), and co-cultured with irradiated APCs $\left(1 \times 10^{5}\right.$ per well $)$ in the presence of Cry j 1 protein $(10 \mu \mathrm{g} / \mathrm{ml}$; Hayashibara Biochemical Laboratories Inc., Okayama, Japan) or tetanus toxoid ( $2 \mu \mathrm{g} /$ $\mathrm{ml}$; Calbiochem, Darmstadt, Germany) in 96-well round-bottomed plates (Becton Dickinson Labware, Franklin Lakes, N.J., USA) in a final volume of $200 \mu \mathrm{l}$ AIM-V medium (Invitrogen) 
containing $10 \%(\mathrm{v} / \mathrm{v})$ human AB serum. For HLA-DPB1*0501 donors, HLA-DPB1*0501-restricted Cry j 1 peptide (position 61-75: GATRDRPLWIIFSGN) was also used as an antigen for cell culture $[14,15]$. Following 6 days of incubation at $37^{\circ} \mathrm{C}$ in a $5 \% \mathrm{CO}_{2}$ atmosphere, responder cells and supernatants were harvested.

\section{Flow Cytometry}

The proliferation of CD4+ and CD4+CD25- cells was measured by flow cytometry on the basis of CFSE dilution. Harvested CFSE-labeled responder cells were resuspended, incubated with APC-conjugated anti-CD4 monoclonal antibodies (mAb) (BD Pharmingen) for $30 \mathrm{~min}$ at $4^{\circ} \mathrm{C}$, and washed twice with phosphate-buffered saline (PBS) containing $0.1 \%$ FBS and $0.1 \% \mathrm{NaN}_{3}$. Five microliters of 7-amino actinomycin $\mathrm{D}$ was added prior to flow cytometry analysis. Viable cells were gated based on negative 7-amino actinomycin D staining. CFSE data analysis was performed using ModFit LT software provided by Verity Software House (Topsham, Me., USA).

\section{ELISA}

Harvest supernatants were stored frozen at $-80^{\circ} \mathrm{C}$ until the cytokine concentrations were determined. IFN- $\gamma$, IL-5 and IL-10 ELISA (Endogen, Pierce Biotechnology Inc., Rockford, Ill., USA) were used to quantify cytokines in the supernatants according to the manufacturer's instructions. The detection limit was $2 \mathrm{pg} / \mathrm{ml}$ for IFN- $\gamma$ and IL-5, and $3 \mathrm{pg} / \mathrm{ml}$ for IL-10.

\section{CD4+CD25+ Treg Culture and IL-10 ELISPOT Assays}

CD4+CD25+ Treg cells $\left(5 \times 10^{4}\right)$ isolated using regulatory T cell separation kit were stimulated with anti-CD3/anti-CD28 expander beads (Miltenyi Biotec) in AIM-V medium containing 5\% (v/v) human AB serum and IL-2 (1,000 IU/ml) in 96-well plates $\left(5 \times 10^{4}\right.$ cells/well). On day 7, CD4+CD25+ Treg cells were harvested, washed and tested by ELISPOT, which was performed in 96-well flat-bottomed plates (Millipore, Bedford, Mass., USA). Briefly, the plates were coated overnight at $4^{\circ} \mathrm{C}$ with $10 \mu \mathrm{g} / \mathrm{ml}$ anti-human IL-10 mAb (9D7; Mabtech, Nacka Strand, Sweden). Dendritic cells (DCs) were generated by culturing plastic adherent cells in AIM-V medium supplemented with 1,000 u/ml GMCSF and $10 \mathrm{ng} / \mathrm{ml} \mathrm{IL-4.} \mathrm{On} \mathrm{day} \mathrm{7,} \mathrm{DCs} \mathrm{were} \mathrm{harvested} \mathrm{and} \mathrm{used}$ as APCs. DCs were pulsed with a Cry j 1 protein $(10 \mu \mathrm{g} / \mathrm{ml})$, irradiated and plated at $2 \times 10^{4}$ cells/well. CD4+CD25+ Treg cells $\left(1 \times 10^{5}\right.$ cells/well $)$ were added to AIM-V medium at a final volume of $200 \mu \mathrm{l}$. The plates were incubated at $37^{\circ} \mathrm{C}$ for $48 \mathrm{~h}$. After incubation, the plates were washed with PBS/0.05\% Tween 20, and supplemented with biotinylated anti-IL-10 mAb (12G8; Mabtech). After $2 \mathrm{~h}$ of incubation, plates were washed with PBS/0.05\% Tween 20, and developed with streptavidin-alkaline phosphatase (Mabtech) for 1 h. BCIP/NBT substrate (SouthernBiotech, Birmingham, Ala., USA) was added and incubated for $5 \mathrm{~min}$. Spot numbers were automatically determined using a computer-assisted video image analyzer (Zeiss-Kontron, Jena, Germany). The mean number of spots in control wells (no antigen) was subtracted from the mean number of spots in experimental wells. A T cell response to a given Cry $\mathrm{j} 1$ protein was considered to be positive if at least 10 cells per $1 \times 10^{5} \mathrm{CD} 4+\mathrm{CD} 25+\mathrm{T}$ cells secreted IL-10. In these cases, Student's t test was performed to determine whether there was a significant difference between the number of IL-10secreting T cells in Cry j 1-stimulated and unstimulated wells, as described by Nagorsen et al. [16].

Immune Regulation by CD4+CD25+ Regulatory T Cells

\section{Statistical Analysis}

The Wilcoxon matched-pairs test and Student's t test were used for statistical analysis of data. $\mathrm{p}<0.05$ were considered significant. Analyses were performed using Stata 9.0 (Stata Corp., College Station, Tex., USA).

\section{Results}

Proliferative Responses of $\mathrm{CD} 4+$ and $C D 4+C D 25-$ T Cells to Cry j 1 Protein, Cry j 1-Derived Peptide and Tetanus Toxoid

PBMCs obtained from 12 patients with Japanese cedar pollinosis and 6 nonallergic healthy donors were co-cultured in the presence of Cry 1 protein. Nine of 12 patients tested were HLA-DPB1*0501 positive; therefore, PBMCs from these patients were also stimulated with HLADPB1*0501-restricted Cry j 1-derived peptide. Following 6 days of culture, responder CD4+ and CD4+CD25- T cells were evaluated for proliferative responses by CFSE dilution. The proliferative responses varied among the 12 pollen-allergic donors tested. As expected, some donors showed an increased percentage of proliferated cells by the depletion of CD4+CD25+ Treg cells in response to Cry 1 protein and/or Cry j 1-derived peptides. A representative dot plot and histogram are shown in figure 1 . We next compared the percentage of proliferated cells between $\mathrm{CD} 4+$ and $\mathrm{CD} 4+\mathrm{CD} 25-\mathrm{T}$ cells; however, culture of CD4+CD25- T cells with Cry j 1 did not show a substantially enhanced proliferative response when compared with CD4+ T cells (fig. 2a). With respect to a nonallergenic recall protein, tetanus toxoid, proliferative responses were also not increased by the depletion of CD4+CD25+ Treg cells (fig. 2a). On the other hand, no proliferative response to Cry $\mathrm{j} 1$ protein and peptide was found in 6 nonallergic healthy donors tested (data not shown).

\section{Cytokine Production of CD4+ and CD4+CD25-}

T Cells in Response to Cry 1 Protein, Cry j 1-Derived Peptide and Tetanus Toxoid

We evaluated cytokine production, including IFN- $\gamma$, IL-5 and IL-10, from CD4+ and CD4+CD25- T cells in response to Cry j 1 protein, Cry j 1-derived peptide and tetanus toxoid. Not every patient reacted against Cry $\mathrm{j} 1$ protein and/or Cry j 1-derived peptide; however, if they did respond to a given allergen, $\mathrm{CD} 4+$ and $\mathrm{CD} 4+\mathrm{CD} 25-\mathrm{T}$ cells from pollen-allergic donors preferentially produced IL-5, and cytokine production in response to Cry j 1-derived peptide was less than that to Cryj 1 protein. Notably, depletion of CD4+CD25+ Treg cells resulted in the enhancement of IFN- $\gamma(\mathrm{p}<0.01)$, but not IL-5 $(\mathrm{p}=0.61)$ pro- 
Fig. 1. Representative results from patient AR-1. CD4+ and CD4+CD25- T cells were isolated, labeled with CFSE, and cultured with irradiated APCs in the presence of Cry j 1 protein or HLA-DPB1*0501-restricted Cry j 1-derived peptide in 96-well round-bottomed plates. On day 6, responder cells were harvested and proliferation was measured by flow cytometry on the basis of CFSE dilution. a Background levels of proliferative cells in culture without antigen. b, c Percentages of proliferative cells in co-cultures with $\mathrm{CD} 4+$ and CD4+CD25- T cells stimulated with Cry j 1 protein and HLA-DPB ${ }^{*} 0501$-restricted Cry j 1-derived peptide (position 61-75), respectively. The percentages of proliferative cells are given for CD4+CFSE ${ }^{\text {low }}$ (left upper quadrant) cells. Corresponding histograms (bottom) show ModFit-generated profiles of proliferative cells of CD4+ T cells.
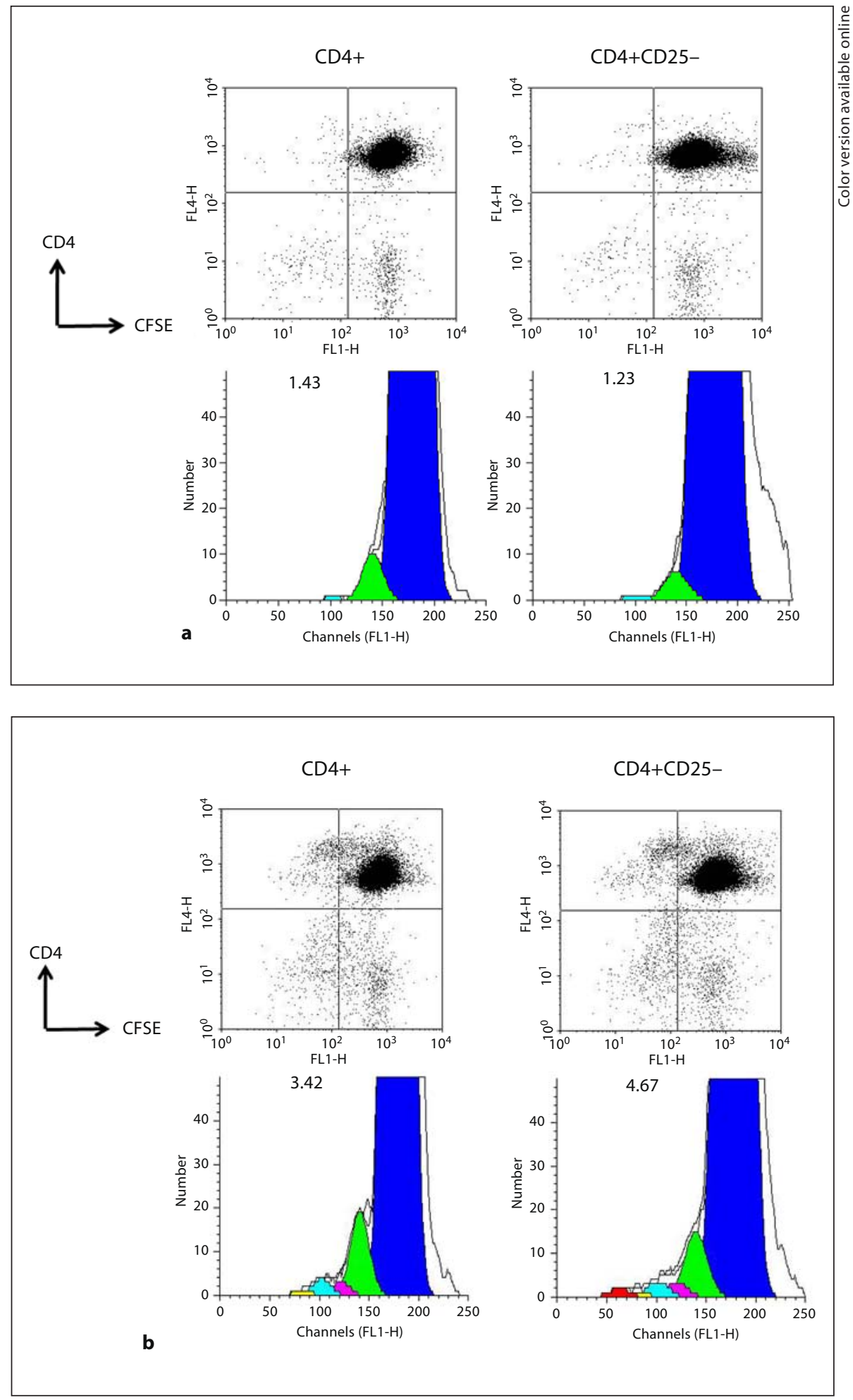


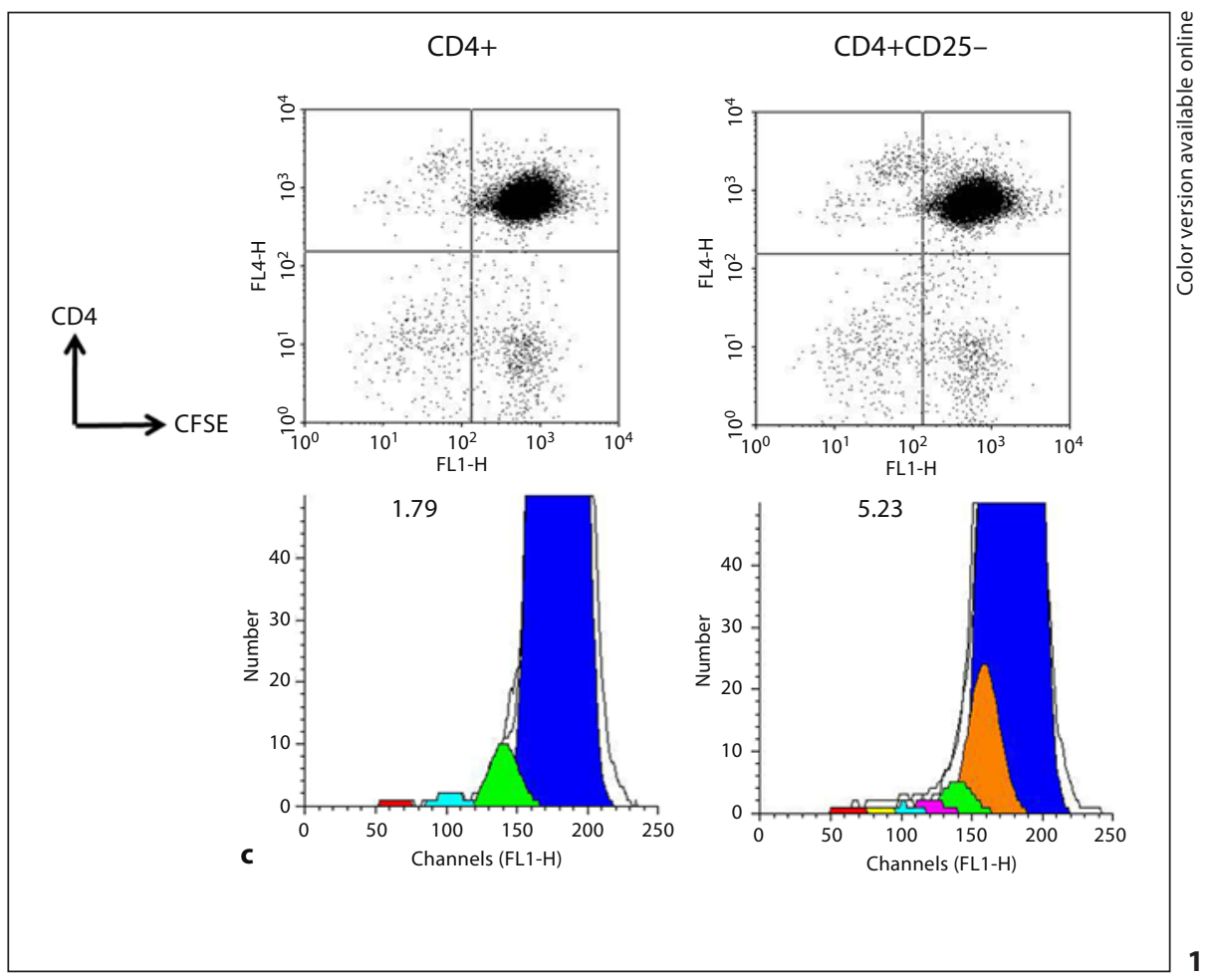

duction, in response to Cry j 1 protein (fig. $2 b, c$ ). Moreover, IL-10 production in response to Cry $j 1$ protein was significantly decreased by the depletion of CD4+CD25+ Treg cells ( $\mathrm{p}<0.01$; fig. $2 \mathrm{~d}$ ). Similarly, Cry j 1-derived peptide-specific IL-10 production also showed a tendency to decrease by the depletion of CD4+CD25+ Treg cells ( $\mathrm{p}=$ 0.08 ; fig. $2 \mathrm{~d}$ ). On the other hand, no substantial cytokine production, including IFN- $\gamma$, IL-5 and IL-10, in response to Cry j 1 protein and Cry j 1-derived peptide was found in nonallergic healthy donors (data not shown). To examine whether the observed difference in IFN- $\gamma$ production was Cry j 1 specific, cells were stimulated with tetanus toxoid. As shown in figure $2 \mathrm{~b}$ and $\mathrm{c}$, both IFN- $\gamma$ and IL-5 were induced by tetanus toxoid, and the amount of IFN- $\gamma$, but not IL-5, was increased significantly by depletion of CD4+CD25+ Treg cells. IL-10 production in response to tetanus toxoid was not significantly changed by the depletion of CD4+CD25+ Treg cells (fig. 2d).

\section{Detection of Cry j 1-Specific IL-10-Producing}

CD4+CD25+ Treg Cells in Patients with Japanese

Cedar Pollinosis

Next, we investigated whether Cry j 1-specific CD4+ CD25+ Treg cells exist in peripheral blood using PBMCs from 4 patients (AR-3, AR-7, AR-8 and AR-9). Purified $\mathrm{CD} 4+\mathrm{CD} 25+\mathrm{T}$ cells were expanded with anti-CD3/anti-CD28 in the presence of IL-2, and Cry $\mathrm{j} 1$-specific responses were examined using IL-10 ELISPOT assays. Interestingly, Cry j 1-specific IL-10-producing CD4+ $\mathrm{CD} 25+\mathrm{T}$ cells were detected in 2 of 3 patients who showed marked reduction of IL-10 production by depletion of CD4+CD25+ Treg cells in this system (table 2).

\section{Discussion}

Currently, Treg cells are a highly heterogeneous population of cells, including the naturally occurring CD4+CD25+ Treg, antigen-induced IL-10-secreting Treg, TGF- $\beta$-secreting Treg, some CD8+ T cells, double- negative T cells and $\gamma \delta$ T cells [17]. Moreover, not only the nature of different Treg cell populations, but also the relationship between Treg populations remains unclear. In this study, we focused on the CD4+CD25+ Treg cell subset in Cry j 1-specific CD4+ T cell responses. CD4+ T cells from nonallergic healthy donors did not show any substantial responses to Cry j 1 protein and Cry j 1-derived peptide, while those from pollen-allergic patients showed 

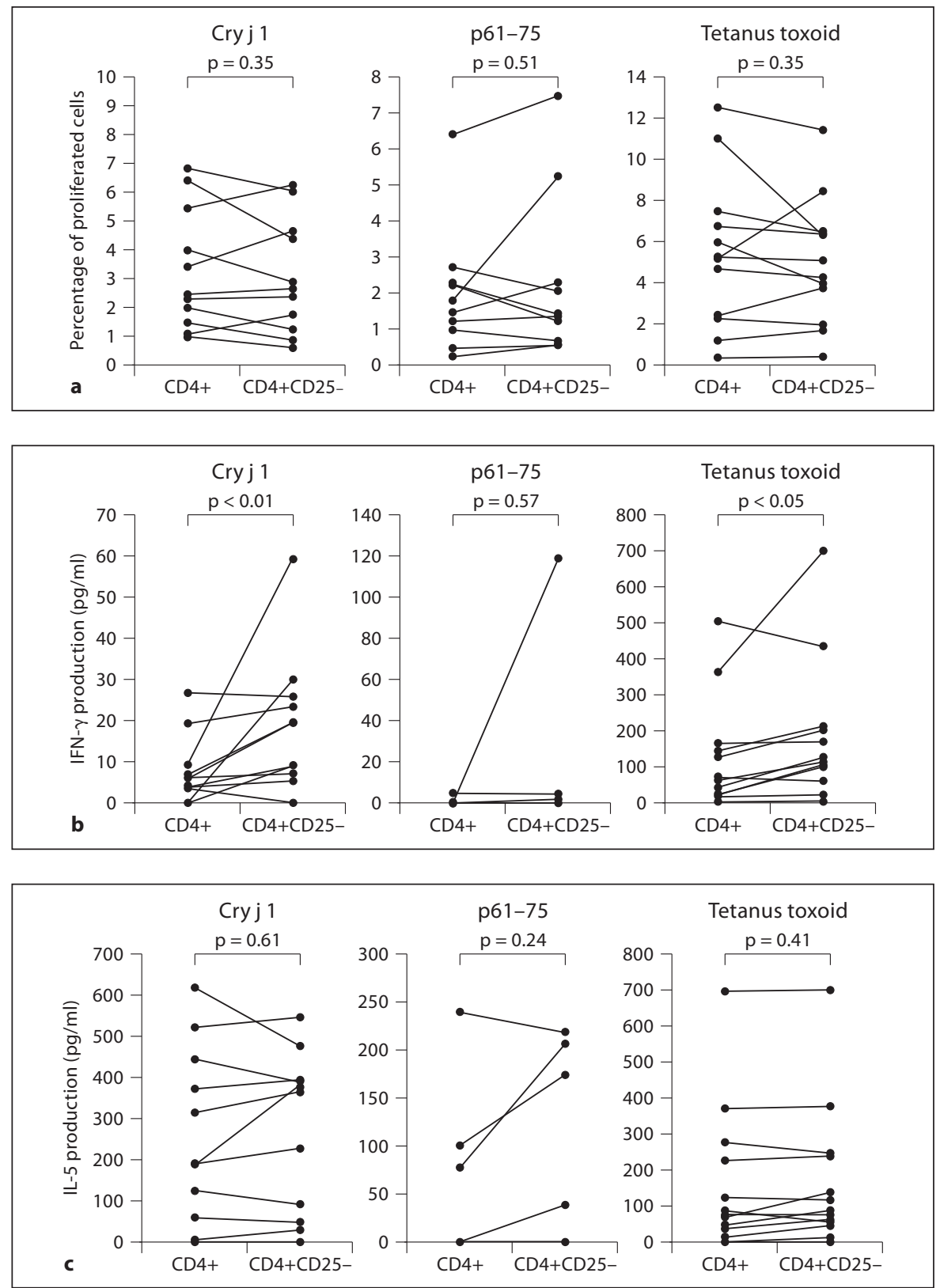

Fig. 2. Proliferative responses and cytokine production in co-cultures with CD4+ and CD4+CD25- T cells stimulated with Cry j 1 protein, Cry j 1-derived peptide (p61-75), or tetanus toxoid in pollen allergic donors. Isolated $\mathrm{CD} 4+$ and $\mathrm{CD} 4+$ CD25- T cells were cultured with irradiated APCs in the presence of Cry $j 1$ protein, Cry j 1-derived peptide or tetanus toxoid. Following 6 days of incubation, responder cells and supernatants were harvested. The percentages of proliferative cells (a) were measured by flow cytometry on the basis of CFSE dilution. IFN- $\gamma(\mathbf{b})$, IL-5 (c) and IL-10 (d) concentrations were measured by ELISA.

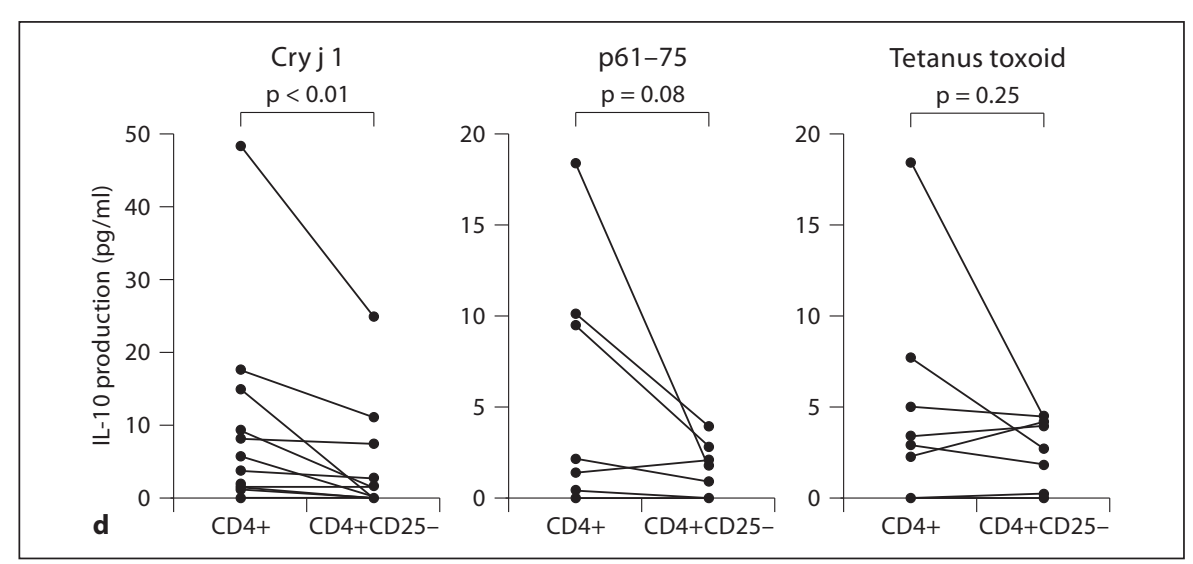


Table 2. Frequency of Cry j 1-specific IL-10-producing cells in CD4+CD25+ T cells and alteration of IL-10 production by the depletion of CD4+CD25+ T cells

\begin{tabular}{llll}
\hline $\begin{array}{l}\text { Pollen-allergic } \\
\text { donors }\end{array}$ & $\begin{array}{l}\text { IL-10 spot- } \\
\text { forming cells }\end{array}$ & \multicolumn{2}{l}{ IL-10 production, pg/ml } \\
\cline { 3 - 4 } & & CD4+ & CD4+CD25- \\
\hline AR-3 & 17 & 17.6 & 11.1 \\
AR-7 & $\mathbf{1 8}$ & 15.0 & 0 \\
AR-8 & $\mathbf{1 2}$ & 9.3 & 1.5 \\
AR-9 & 0 & 0 & 0 \\
\hline
\end{tabular}

Data are the mean numbers of spots $/ 10^{5} \mathrm{CD} 4+\mathrm{CD} 25+\mathrm{T}$ cells/well in ELISPOT assays. The mean number of spots in control well (no antigen) was subtracted from the mean number of spots in experimental wells.

Isolated CD4+ and CD4+CD25- T cells were cultured with irradiated APCs in the presence of Cry J 1 protein. Following 6 days of incubation, supernatants were harvested and IL-10 production was measured by ELISA. Bold numbers indicate positivity for IL10-producing CD4+CD25+ T cell responses to Cry j 1 protein. various patterns of responses. First, we assessed the alteration of proliferative response and cytokine production by depletion of CD4+CD25+ Treg cells. Some patients showed enhanced immune responses to Cry $\mathrm{j} 1$ by depletion of CD4+CD25+ T cells. This finding indicates that CD4+CD25+ Treg cells may be, in part, responsible for the downregulation of Cry $\mathrm{j} 1$-specific CD4+ T cell responses in certain individuals, whereas there was no significant difference between CD4+ and CD4+CD25- cells in proliferative responses and IL-5 (Th2-type) production in all pollen-allergic patients. To date, in pollen-allergic patients, the functional deficiency of CD4+CD25+ Treg cells is still controversial. Thunberg et al. [18] have demonstrated that CD4+CD25+ Treg cells from allergic patients failed to suppress birch pollen-stimulated proliferation. Similarly, Skrindo et al. [19] have demonstrated that no increase in proliferation or Th2 cytokine production was observed in cell cultures depleted of CD4+CD25+ $\mathrm{CD} 127^{\text {lo }}$ cells compared with undepleted PBMCs in allergic patients. In contrast, Bellinghausen et al. [8] have shown that $\mathrm{CD} 4+\mathrm{CD} 25+\mathrm{T}$ cells from the majority of allergic donors inhibited the proliferation and Th1 (IFN$\gamma$ ) and Th2 (IL-4 and IL-5) cytokine production of CD4+CD25- T cells. Interestingly, several reports have suggested that allergen exposure affected the regulatory function of CD4+CD25+ Treg cells in pollen-allergic patients, namely, CD4+CD25+ Treg cells from allergic patients were defective in downregulating pollen-induced proliferation and/or IL-5 production during the pollen season [7, 11]. In our experimental system, PBMCs were obtained outside the pollen season. Nevertheless, no increase in proliferation responses and IL- 5 production was observed, suggesting that the suppressive function of
CD4+CD25+ Treg cells in patients with Japanese cedar pollinosis may not be affected by the pollen season. On the other hand, IFN- $\gamma$ (Th1-type) production was significantly upregulated by the depletion of CD4+CD25+ T cells. Similar phenomena are observed in cytokine production upon stimulation with tetanus toxoid; therefore, the lack of augmented Th2 cytokine production in cell cultures depleted of CD $4+C D 25+T$ cells could not be explained by the strongly Th2-skewed immune response to Cry $\mathrm{j} 1$ in pollen-allergic patients. It has been shown that Th2 cells have lower susceptibility than Th1 cells to the suppressive activity of CD4+CD25+ Treg cells [20]. Indeed, Thunberg et al. [18] have shown that the production of Th1, but not Th2 cytokines, was suppressed by CD $4+C D 25+$ cells from both allergic patients and nonallergic controls upon stimulation with birch pollen extract. Likewise, Grindebacke et al. [11] have demonstrated that in allergic patients, the capacity of CD4+CD25+ Treg cells to suppress IFN- $\gamma$, but not IL-5 production is retained. Additionally, more recently, several studies have revealed that Treg cells can be divided into several subsets based on their differential expression of transcription factors [21, 22]. The transcription factor IFN-regulatory factor 4 was shown to be required for Treg cells with the ability to suppress Th2 responses, whereas the induction of Th1-specifying transcription factor T-bet expression by Treg cells resulted in Treg cells with suppressive properties to Th1 responses. Although it remains unclear how each Treg subset contributes to suppress Cry j 1-specific CD4+ T-cell responses, not only the different susceptibility of Th cells to Treg cells, but also the phenotypic and/or functional diversity of Treg cells, may affect the suppression of Cry j 1-specific immune responses in pollen-allergic patients. 
Another important finding of this study is that Cry $j$ 1-specific IL-10-producing CD4+CD25+ Treg cells existed in pollen-allergic donors. Depletion of CD $4+C D 25+$ Treg cells resulted in the reduction of IL-10 production upon stimulation with Cry j 1 ; therefore, we investigated the presence of Cry j 1-specific IL-10-producing CD4+ CD25+ Treg cells using IL-10 ELISPOT assays. In general, the suppressive effect of CD4+CD25+ Treg cells is known to be dose dependent, cell-contact dependent, cytokine independent and antigen nonspecific; however, several reports have demonstrated that allergen-specific IL-10-producing CD4+CD25+ T cells exist in peripheral blood in allergic patients $[12,13]$. Furthermore, such $\mathrm{T}$ cells have also been shown to be induced and increased in patients undergoing immunotherapy $[23,24]$. Data from our study and others suggest that IL-10-producing CD4+CD25+ T cells exist and play an important role in the regulation of $\mathrm{CD} 4+\mathrm{T}$ cell responses to allergens in certain allergic patients. The possibility to induce and increase such $\mathrm{T}$ cells in vitro and/or in vivo may be of great interest for the development of a novel immunotherapy.
Taken together, at least in a subpopulation of pollenallergic patients, CD4+CD25+ Treg cells are sufficiently able to suppress immune responses to Cry j 1; however, their inhibitory activities appear to be regulated by a variety of factors, including allergen exposure, type of Th response and allergic status. Moreover, Cry j 1-specific IL-10-producing CD4+CD25+ Treg cells exist in the peripheral blood of pollen-allergic donors. Development of allergic diseases can result from an inappropriate balance between Treg cells and Th2 cells upon allergen stimulation [25]; therefore, a better understanding of IL-10-producing CD4+CD25+ Treg cells in the suppressive mechanism is necessary to develop more effective immunotherapy in the future.

\section{Acknowledgements}

This work was supported in part by a grant from the Ministry of Education, Culture, Sports, Science and Technology, Japan, and by a Health Science Research Grant from the Ministry of Health and Welfare, Japan.

\section{References}

1 Levings MK, Sangregorio R, Roncarolo MG: Human CD25+CD4+ T regulatory cells suppress naïve and momory $\mathrm{T}$ cell proliferation and can be expanded in vitro without loss of function. J Exp Med 2001;193:1295-1302.

-2 Ng WF, Duggan PJ, Ponchel F, Matarese G, Lombardi G, Edwards AD, Isaacs JD, Lechler RI: Human CD4+CD25+ cells: a naturally occurring population of regulatory $\mathrm{T}$ cells. Blood 2001;98:2736-2744

3 Jonuleit H, Schmitt E, Stassen M, Tuettenberg A, Knop J, Enk AH: Identification and functional characterization of human $\mathrm{CD} 4+\mathrm{CD} 25+\mathrm{T}$ cell with regulatory properties isolated from peripheral blood. J Exp Med 2001;193:1285-1294.

4 Hawrylowicz CM: Regulatory T cells and IL10 in allergic inflammation. J Exp Med 2005 202:1459-1463.

5 Taylor A, Verhagen J, Akdis CA, Akdis M: T regulatory cells and allergy. Microbes Infect 2005;7:1049-1055.

-6 O'Garra A, Vieira P: Regulatory T cells and mechanisms of immune system control. Nat Med 2004;10:801-805.

-7 Ling EM, Smith T, Nguyen XD, Pridgeon C, Dallman M, Arbery J, Carr VA, Robinson DS: Relation of CD4+CD25+ regulatory Tcell suppression of allergen-driven T-cell activation to atopic status and expression of allergic disease. Lancet 2004;363:608-615.
-8 Bellinghausen I, Klostermann B, Knop J, Saloga J: Human $\mathrm{CD} 4{ }^{+} \mathrm{CD} 25^{+} \mathrm{T}$ cells derived from the majority of atopic donors are able to suppress $\mathrm{T}_{\mathrm{H}} 1$ and $\mathrm{T}_{\mathrm{H}} 2$ cytokine production. J Allergy Clin Immunol 2003;111:862-868.

-9 Bellinghausen I, Konig B, Bottcher I, Knop J, Saloga J: Regulatory activity of human CD4+ CD25+ T cells depends on allergen concentration, type of allergen and atopy status of the donor. Immunology 2005;116:103-111.

10 Anderson AE, Mackerness KJ, Aizen M, Carr VA, Nguyen D, Du Pre F, Durham SR, Robinson DS: Seasonal changes in suppressive capacity of CD4+ CD25+ T cells from expansion of effector $\mathrm{T}$ cells among the CD25+ population. Clin Exp Allergy 2009; 39:1693-1699.

11 Grindebacke H, Wing K, Anderson AC, Suri-Payer E, Rak S, Rudin A: Defective suppression of Th2 cytokines by CD4+CD25+ regulatory $\mathrm{T}$ cells in birch allergics during birch pollen season. Clin Exp Allergy 2004; 34:1364-1372.

12 Maggi L, Santarlasci V, Liotta F, Frosali F, Angeli R, Cosmi L, Maggi E, Romagnani S, Annunziato F: Demonstration of circulating allergen-specific $\mathrm{CD} 4^{+} \mathrm{CD} 25^{\text {high }} \mathrm{Foxp}^{+} \mathrm{T}$ regulatory cells in both nonatopic and atopic individuals. J Allergy Clin Immunol 2007; 120:429-436.
13 Nagato T, Kobayashi H, Yanai M, Sato K, Aoki N, Oikawa K, Kimura S, Abe Y, Celis E, Harabuchi Y, Tateno M: Functional analysis of birch pollen allergen Bet $\mathrm{v}$ 1-specific regulatory T cells. J Immunol 2007;178:11891198.

14 Sone T, Morikubo K, Miyahara M, Komiyama N, Shimizu K, Tsunoo H, Kino K: T cell epitopes in Japanese cedar (Cryptomeria japonica) pollen allergens: choice of major $\mathrm{T}$ cell epitopes in Cry j 1 and Cry j 2 toward design of the peptide-based immunotherapeutics for the management of Japanese cedar pollinosis. J Immunol 1998;161:448457.

15 Chikamatsu K, Sakakura K, Matsuoka T, Endo S, Takahashi G, Matsuzaki Z, Masuyama K: Analysis of T-helper responses and FOXP3 gene expression in patients with Japanese cedar pollinosis. Am J Rhinol 2008; 22:582-588.

16 Nagorsen D, Keilholz U, Rivoltini L, Schmittel A, Letsch A, Asemissen AM, Berger G, Buhr HJ, Thiel E, Scheibenbogen C: Natural T-cell response against MHC class I epitopes of epithelial cell adhesion molecule, her-2/ neu, and carcinoembryonic antigen in patients with colorectal cancer. Cancer Res 2000;60:4850-4854 
17 Ozdemir C, Akdis M, Akdis CA: T regulatory cells and their counterparts: masters of immune regulation. Clin Exp Allergy 2009; 39:626-639.

18 Thunberg S, Akdis M, Akdis CA, Gronneberg R, Malmstrom V, Trollmo C, van Hage $\mathrm{M}$, Gafvelin G: Immune regulation by CD4+CD25+ $\mathrm{T}$ cells and interleukin-10 in birch pollen-allergic patients and non-allergic controls. Clin Exp Allergy 2007;37:11271136.

19 Skrindo I, Farkas L, Kvale EO, Johansen FE, Jahnsen FL: Depletion of $\mathrm{CD} 4^{+} \mathrm{CD} 25^{+}$ $\mathrm{CD} 127^{\mathrm{lo}}$ regulatory $\mathrm{T}$ cells does not increase allergen-driven $\mathrm{T}$ cell activation. Clin Exp Allergy 2008;38:1752-1759.
20 Cosmi L, Liotta F, Angeli R, Mazzinghi B, Santarlasci V, Manetti R, Lasagni L, Vanin V, Romagnani P, Maggi E, Annunziato F, Romagnani S: Th2 cells are less susceptible than Th1 cells to the suppressive activity of CD25+ regulatory thymocytes because of their responsiveness to different cytokines. Blood 2004;103:3117-3121.

21 Zheng Y, Chaudhry A, Kas A, deRoos P, Kim JM, Chu TT, Corcoran L, Treuting P, Klein U, Rudensky AY: Regulatory T-cell suppressor program co-opts transcription factor IRF4 to control TH2 responses. Nature 2009; 458:351-356.

22 Koch MA, Tucker-Heard G, Perdue NR, Killebrew JR, Urdahl KB, Campbell DJ: T-bet controls regulatory $\mathrm{T}$ cell homeostasis and function during type-1 inflammation. Nat Immunol 2009;10:595-602.
23 Akdis CA, Blesken T, Akdis M. Wuthrich B, Blaser K: Role of interleukin 10 in specific immunotherapy. J Clin Invest 1998;102:98106.

24 Francis JN, Till SJ, Durham SR: Induction of IL-10+CD $4+$ CD $25+T$ cells by grass pollen immunotherapy. J Allergy Clin Immunol 2003; 111:1255-1261.

25 Akdis M,Verhagen J, Taylor A, Karamloo F, Karagiannidis C, Crameri R, Thunberg S, Deniz G, Valenta R, Fiebig H, Kegel C, Disch R, Schmidt-Weber CB, Blaser K, Akdis CA: Immune responses in healthy and allergic individuals are characterized by a fine balance between allergen-specific $\mathrm{T}$ regulatory 1 and T helper 2 cells. J Exp Med 2004;199: 1567-1575. 